\title{
IntemationalJoumal of ArtsandHumanities(IJAH)
}

\section{Ethiopia}

Vol. 7 (2), S/No 25, APRIL, 2018: 40-48

ISSN: 2225-8590 (Print) ISSN 2227-5452 (Online)

DOI: http://dx.doi.org/10.4314/ijah.v7i2.6

\section{The Representation of the African Woman in Male-Dominated Society: A Study of Chinua Achebe's Things Fall Apart and Amma Darko's Beyond the Horizon}

\author{
Gbaguidi, Célestin, PhD \\ Department of English \\ Faculty of Languages, Arts and Communication \\ University of Abomey-Calavi \\ P. O. Box 1069, Abomey-Calavi \\ République du Bénin \\ Tél. + 22997609568 \\ E mail: ggbaguidicelestin@yahoo.fr or celestin.gbaguidi@uac.bj
}

\begin{abstract}
This paper highlighted and analysed the portrayals of the traditional African women in selected postcolonial Anglophone African writers' literary works such as Chinua Achebe's Things Fall Apart (1958) and Amma Darko's Beyond the Horizon (1995). Although they are of opposite sex, different nationalities and generations they condemn the phallocentric organisation of the African societies where women are nothing but naïve, second-rank and sexually addicted people, reproducers, mere commodities and men's appendage, just to name a few. Interestingly, Achebe and Darko are convinced that it is time to do justice to women. Therefore, post-colonial criticism offers the lenses through which female characters can regain power. This paper posited that some writers show concern for the relegation of the African woman to subordination because they are not satisfied with some African male writers' misrepresentation of the African woman. For this reason, they decide to give proofs of the real role of the African woman in her community.
\end{abstract}

Key Words: African woman, biased image, subordinate, patriarchy, exploit, fairness

\section{Introduction}

The promotion of equal rights for both men and women is the concern of a number of organisations worldwide. In the western countries, this is indeed the best formula that has been found to liberate women from vassalage due to men's selfishness as well as to the steady "civilisation" that favours only men.

Undoubtedly, Africa is a continent where the trivialisation of the fair sex is common practice; indeed, the black continent is basically controlled by the masculine sex. To buttress the assertion that Africa is 
mostly a male-controlled society, Mikell (1997) postulated that: "in Africa, female subordination takes intricate forms grounded in traditional culture, particularly in the 'corporate' and 'dual-sex' patterns that Africans have generated throughout their history" (p. 9). Therefore, Africa's tradition is strongly in favour of male dominance. In that vein, Anyidoho et al. (2016) pointed it out that "Patriarchy - a social system within which male authority is central to social, political and economic organisation - is a feature of most human societies. Consequently, women's lives everywhere are marked by distinct patterns of disadvantage on many fronts: at home, in the labour market, and in the larger society" (p. 5). Likewise, Busia (1986) contended that "women are always lovers, wives, or blood relatives of central male characters, and have significance in the texts only insofar as they affect those characters". Similarly, a critic, Strong-Leek (2001) pointed out that: "In Things Fall Apart [...], women are viewed mainly as child bearers and help mates for their husbands" (p. 30). It is of a crucial interest to post-colonial discourse for two major reasons. First, patriarchy is an exertion of "analogous forms of domination" (Ashcroft et al. 2007, p. 93) over submissive women. Unfortunately, African women are seen only as helpful companions and subjugated mercilessly to men's authorities in their communities; their drudgery is always viewed as a must. They are indeed seen as nonentities in the communities with no social rank. All these negative perceptions of women in the African society are mirrored in postcolonial fiction. Rightly and rightfully, Anyidoho et al.(2016) posited that: "The portrayal of women in [...] creative literature is tied primarily to women's 'ideal' roles as wives and mothers" (p. 5).Such a situation that has ever belittled women's efforts and existence deserves particular attention and ideology; hence the belief that women should have the same rights and opportunities as their male counterparts and what they really represent. Interestingly, Anyidoho et al. (2016) opined that "As a counter to these negative representations, women writers have taken pains to portray women in more sympathetic and dignified ways" (p.16). This paper aimed to explore and screen the true image of African women and how challenging it is for them to make again places brighter for themselves and for the future generations in patriarchal communities. With the theory of post-colonial criticism, this paper posited that some African creative writers show concern for the relegation of the rural African woman to subordination because they are not satisfied with how the rural African woman has so far been treated in literature by some African male writers who dismiss her value and so decide to give proofs of the real role of the African woman in her community.

\section{Patriarchal Societies and Women in Darko's Beyond the Horizon and Achebe's Things Fall} Apart

African traditions instil into females values like unconditional love, attention, tenderness, respect, submission and availability to serve their husband, whom they take as superior to them. This tradition contributes strongly to African women's trivialisation. They are seen as objects and the weaker sex. Traditional virtues and beliefs make African women defenceless and they resign themselves to loveless and restrictive union, economic exploitation, physical and psychological violence. Those are indeed, the images of the conventional African woman in man-dominated societies. Nevertheless, emancipated African women, through schooling, happen to subvert somehow the plague and this change shows through African women's creative writings. In this wake, Kofi Owusu" (1999) cited African female writers, like Aidoo, who contribute to "ongoing attempts to rescue the African woman from the fringes of African literature and restore flesh, blood, voice and credibility to her" (p. 342).

\section{African Women's Commodification}

The African socio-traditional realities are an ideal breeding ground for women's exploitation and subjugation by male oppressors. Women are nurtured to acquire traditional education and qualities, which prepare them for a relationship of dependence on men. These qualities include gentleness, passivity, submission and striving to always please men. It is therefore not surprising that these women are submissive to their men irrespective of the maltreatment they daily experience. 
In Amma Darko's Beyond the Horizon,for instance, the autodiegetic narrator Mara suffers the diktat of patriarchy in that she has no right to choose her own partner for life. Hence, Akobi is imposed on her by her father, heavily indebted to Akobi's father. Meanwhile, Mara's elder sister suffers similar predicaments and the result is disastrous to the extent that it should be a lesson for her parents regarding marrying their daughters. Mara describes the scene that precedes her arranged marriage in sounding words:

I remember the day clearly. I returned from the village well with my fourth bucket of water of the day when mother excitedly beckoned to me in all my wetness and muddiness, dragged me into her hut and breathlessly told me the 'good news'.

'Your father has found a husband for you' [...] 'a good man!'

All I did was grin helplessly because I clearly remembered the same good news as this that mother had given my older sister two years before. Found, too, by father. And my sister was now a wreck (Darko 1995, pp.3-4).

Mara's father, acting as an imperialist in a postcolonial setting, compels his daughters to marry men he has chosen for them. On this note, Diop (1989) held the view that a male-dominated society denies women their rights, subjugating and making them properties in a strict hierarchical system of family where the man (husband or father) is supreme and has power of life and death over women. Since "both patriarchy and imperialism can be seen to exert analogous forms of domination over those they render subordinate" (Ashcroft et al. 2007, p. 93). Mara's father's behaviour is a reminder of the master-servant relationship between the white settler (colonizer) and the colonized.

In such a traditional African society, women's frame of mind cannot change anything, whether they agree or not, they are compelled to marry men they do not know and who do not love them either. As Richmond Amgbo Blay (2014) aptly put it: "The African women are also portrayed as incapable of making their own decisions in life and that men have to take decisions for them. Mara and her sister are not allowed to make choices as regards marriage partners and as result these men chosen for them treat them with disrespect" (p. 112). As we can see, women in patriarchal societies do not have any choice but accept the crushing and overbearing system with its concomitant difficulties. Foucault (1980) pointed out pertinently: "individuals, who do not comply with the social norms of the dominant discourse in society, are branded as "abnormal"' (p. 7). Unfortunately, the patriarchal community is used to abusing female children basing on their submission caused by tradition. If these female characters are consulted in an important issue like wedding, they can marry men that they know and love, which can avoid them the misfortune and troubles that marrying unknown men generally bring about. And African tradition is powerful in women's commodification regardless their age.

Amazingly, girls under age are forced into marriage as a compensation for their domineering parents' mistakes or debts. In Achebe's Things Fall Apart, a fresh virgin girl from the village Mbaino is given to Ogbuefi Udo, a male character, to replace his murdered wife. The innocent girl from Mbaino is likened to a commodity sold without consent; her opinion never matters. The heterodiegetic narrator informs the narratee about the fateful decision to marry that innocent and defenceless girl off to Ogbuefi Udo in that way: "the elders, or ndichie, met to hear a report of Okonkwo's mission. At the end they decided, as everybody knew they would, that the girl should go to Ogbuefi Udo to replace his murdered wife" (2008, p. 10). This is to show that women or young girls in traditional Africa serve only men's whims. The virgin girl knows nothing about the old man she is married to as is the case with Mara in Darko's Beyond the Horizon. To buttress this, Mara's lament shows her frustration about her forced marriage with Akobi: "I just didn't know him. I was living with this man and 
sleeping in one room with him and I just didn't know him" (Darko 1995, p. 21). It appears that Mara's oppressive ordeal depicts African women as defenceless and speechless in a hostile man-dominated society.

\title{
Women as a Worthless Beings
}

Chinua Achebe and Amma Darko intend to explore the contours of the representations of women in patriarchal sub Saharan African societies. In this respect, in Darko's Beyond the Horizon women are presented as people who are submissive, naïve and inferior to men. The men in this novel symbolised by Akobi and Osey capitalise on the docility, naivety and inferiority complex of Mara and Vivian to batter and exploit them with ease. As a matter of fact, both men use Mara and Vivian as sex slaves to amass wealth without commission for the exploited women. Besides, due to their family education, these women daren't conceal a part of the earning that they get from selling sex. The speech made by the autodiegetic narrator, Mara, when her oppressive husband informs her of her impending flight to Germany buttresses the argument that the African woman is viewed as unassuming, submissive, naïve and with an inferiority complex:

\begin{abstract}
'Akobi', I said dreamily, 'whatever you say I am sure is the right thing. What you decide on I am sure is the right thing. I am sure Akobi'. And it was like I was in the middle of a dream, being made love to by Don Juan. There was nothing Akobi would have said at that moment that I wouldn't have done. His word at that moment was holy. And not even the Pope could have thwarted me. If Akobi had suddenly suggested that I allowed myself to be beheaded, that cutting my head off at that moment was the right thing to do, I would readily and gladly have given in still gone hopping headless, singing hallelujah unto him. So taken in was I by him (Darko 1995, p. 36).
\end{abstract}

Deeply rooted in the African customs, and due to the phallocentric standpoint that the African woman has to swallow men's ruling and that it is men who enjoin or rule women and as a result, women have no choice except succumb to men's injunctions, evidently the female character Mara lets herself be tamed by her spouse. A proof of women's relegation to the rank of inferiority or worse still their social exclusion from decision-making bodies in phallocentric societies is also noticeable with Achebe's Things Fall on the occasion of the popular meeting intending to decide on the stance Umuofians should take up regarding the neighbouring village Mbaino where somebody has dared to murder a daughter from Umuofia:

In the morning the market-place was full. There must have been about ten thousand men (emphasis mine) there, all talking in low voices [...]. Many others spoke, and at the end it was decided to follow the normal course of action. An ultimatum was immediately dispatched to Mbaino asking them to choose between war on the one hand, and on the other the offer of a young man and a virgin as compensation. (Achebe 2008, p. 9)

Oddly enough, the aforementioned meeting is of paramount importance for the survival of the people of Umuofia since all of them, comprising women, are jointly and severally liable for the decision they will have to make nevertheless, the male sexists exclude women or play down their attendance at the meeting. Those women's marginalisation simply implies that African women do not matter as regards the decision making because they are of no value in this patriarchal society. The representation of the African woman as a worthless being in a phallocentric context culminates in Achebe's first novel when the male character Okonkwo breaks the sacred Week of Peace by battering his youngest wife, Ojiugo. In fact, the elders of the clan do not punish Okonkwo for committing such an act of violence against his wife but they fine him for the moment when he batters her because countless acts of 
violence against women in their society remain unpunished. To show the seriousness of Okonkwo's offence towards their gods at that sacrosanct moment, the old man Ezeani sermonises the offender in this way: "You have committed a great evil [...]. It was the first time for many years that a man had broken the sacred peace. Even the oldest men could only remember one or two other occasions somewhere in the dim past" (Achebe 2008, pp. 24-25). It comes out that after Okonkwo's flogging of his youngest wife, there is a public commotion "not because of the physical battering, but, rather the timing of the occurrence" (Strong-Leek 2001, p. 31). As if to buttress this standpoint, Iyasere (1969) put fittingly: "the peace of the tribe as a whole takes precedence over personal considerations" (p. 94). Facing such physical abuse and torments suffered by African women, post-colonial African feminists advocate a collective awareness of the pitiful fate booked for the African woman by patriarchal societies and an equal treatment of all the members of the society regardless of their gender. In the context of this discriminatory patriarchal rule, African women are viewed as sex objects.

\section{African Women as Sex Commodities}

Post-colonialism postulates that independent African countries are still under the influence of European colonisers' cultures, thus disrupting the social fabric of African societies (Ashcroft et al. 2007, p. 168). Indeed, in Beyond the Horizon, for instance, African women are portrayed as sex commodities. The domineering male character Akobi, Mara's husband, treats her as a sex commodity and pounces on her like a beast whenever he feels like having sex. Surprisingly, in the couple's sex lives, Akobi sees her as an object that has no sexual feelings so anytime he wants to have sex with her he just beckons her to sleep on the mattress, pounces on her and when he is satisfied he orders her to go back to her room. The heterodiegetic narrator Mara recounts her afflictions with her 'spouse' thus:

Cool composed and authoritative, he indicated with a pat of his hand on the space beside him that I should lie down beside him. I did so, more out of apprehension of starting another fight than anything else. Wordlessly, he stripped off my clothes, stripped off his trousers, turned my back to him and entered me. Then he ordered me off the mattress to go and lay out my mat because he wanted to sleep alone (Darko 1995, p. 22).

The narratee can sense a kind of animosity that Akobi has towards his 'wife' Mara, who is unfortunately seen, in this condition, as a sex object, a sexual partner instead of a wife. If Mara were considered as Akobi's real wife and has been chosen by himself, she would be treated with respect not as a rock with no feelings. As Blay (2014) pointed out cogently: "In the face of imperialist patriarchy, traditional African women in post-colonial Africa appear to have lost their image, myth and sacredness that represented their being and social existence" $(2014$, p. 3). Mara's confidant, Mama Kiosk, tries to catch Mara's attention to the inconsiderate attitude of her husband by raising her consciousness: "Your husband is one of those men who have no respect for village people [...]. Tradition demands that the wife respect, obey and worship her husband but it demands, in return, care, good care of the wife. Your husband neglects you and yet demands respect and complete worship from you. That is not normal"(Darko 1995, p.13). Furthermore, the attitude of the male character Osey towards his friend's wife leaves much to be desired in that Osey, Akobi's purported bosom friend, weirdly decides to have sex with Mara. By so doing, he considers her as a sex commodity that can be shared. The narratee seems to be completely taken aback as the sexual harasser finds his sexual deviancy normal facing the autodiegetic narrator's scolding:

There was even a note of anger in his tone; I must say, very much to my stupefaction, since, after all, I felt that I was the one entitled to be angry, not him. I couldn't understand the world any longer. I mean, here was a man openly claiming to be my husband's best friend trying to seduce me, and who was not 
only bored and angry at my reaction, my threat to report him, but goes out of his way to call it monkey drama (Darko 1995, pp. 65-66).

It appears that the sexual pervert male character Osey has no respect for female characters and intends to perpetrate an amoral deed by attempting to have sex with his friend's wife. Akobi's disrespect to women, in general, and to his wife, in particular, has no boundary. Indeed, even in Germany Akobi continues to treat Mara as a sex object. Undoubtedly, the way patriarchal societies treat women surely hinders women's social growth. Worse still, Akobi and his friend Osey introduce their wives Mara and Vivian respectively into prostitution in Germany to make both ends meet in Germany, which they have thought to be the Promised Land. The exploitative husbands get the dirty money out of their wives and spend it carelessly. This shows that African women in Darko's Beyond the Horizon are represented as people who can easily be exploited by men. Very piqued out of her exploitation, Vivian, Osey's wife, gives an account of her sorrow as follows: "Even the money that I make, he controls it. I can't buy anything without his consent, not even for my own mother at home." (Darko 1995, p. 89). Hence since "the experiences of women in patriarchy and those of colonized subjects can be paralleled in a number of respects" (Ashcroft et al. 2007, p. 93), both feminist and post-colonial policies fight such supremacy through the recommendation of a social change in women's status by changing the way malewritten fiction projects African women. Peter buttresses this standpoint when he convincingly points out that feminism "wants society to change its ideas on patriarchy and accept women as being a valuable part of society" (2010: 30). What of women represented as saleable articles in patriarchal societies?

\section{Women as Commercial Articles}

One of the despicable side of patriarchy is that it views women as marketable items. Indeed, in Beyond the Horizon women are shown as property that can be sold to the highest bidder or something that can be used to pay back one's debt. On this note, Mara is given out to the highest bidder, Akobi. Interestingly, Blay (2014) writes that:

Additionally, African women are presented to the readers as individuals who should be given to the highest bidder. Mara is given out to Akobi whose father presents two cows, four healthy goats, four lengths of cloth, beads, gold jewelry and two bottles of London Dry Gin. In the community of Naka where the story is set Akobi's father is the only person who can afford these. Hence Mara is sold to Akobi very expensively in order that her father gets wealth and other material gains (p. 110).

Helplessly, Mara resigns herself to her father's decision to marry her to Akobi without even consulting her. Consequently, she withstands the neglect and abuse that Akobi heaps on her because she believes, as a true conventional African woman, that it is a wife's duty to put up with her husband's whims. The autodiegetic narrator Mara seems to deride her father's scornful and materialistic attitude as regards his female children's wedding: "But father, it appeared, had a different formula for choosing or accepting husbands for his daughters, which took more into consideration the number of cows coming as the bride price than the character of the man"(Darko 1995:4). It is outstanding that Mara's father's interest takes precedence over his daughters' lives; as a true imperialist and member of a male-controlled system, Mara's father sacrifices his daughters' dignity for his sole interests.

In fact, an African woman, like Mara in the patriarchal society of Naka, is seen as an object that can be commercialised for lucrative purposes and that her happiness and blooming do not matter at all. Even though the payment of the bride price raises the African woman's status in the community, it 
sometimes entitles some men to take women as commodities especially when the in-laws exaggerate while setting the amount of the bride price. Women's commodification in the bride price process provides fertile grounds for men's supremacy over them and husbands' tendency to oppress their wives in a patriarchal setting. No wonder the male character Akobi reifies his 'wife' on whom his father has spent a lot of money for the bride price by constantly battering and humiliating her. In fact, one can infer that Akobiis trying to recover the tremendous amount of money his father has spent to 'purchase' her. It is on the basis of the foregoing that the post-colonial African feminists advocate for the equal treatment of all the people in the society irrespective of their sex, race, and religion.

It is also worth mentioning that Akobi and his crony Osey do not show any sign of love toward their so-called wives; hence they treat them with disdain. As a matter of fact, the procurers Akobi and Osey send for their spouses, Mara and Kaye, in their home land, to make them work in a brothel for getting immoral earnings from their exploitation. Unveiling the way the oppressive male characters Akobi and Osey dehumanise Mara, Blay aptly pinpoints that Mara is an immature village girl who "recounts the ordeals she goes through when she is blackmailed into prostitution by her husband and his bosom friend, Osey" (2014: 88). Surprisingly, Akobi spends the immoral earnings on his mistress, Comfort. If Akobi and his ally Osey truly loved their wives, they would not blackmail them into prostitution in Germany. In recounting this devastating condition that she has gone through from her imperialist husband Akobi, the heterodiegetic female character Mara confesses:

I felt drained, so drained that I had asked for a glass of water. My husband brings me from home to a foreign land and puts me in a brothel to work, and what money I make, he uses to pay the rent on his lover's apartment, and to renovate a house for her in her village back home. I came to Gerhardt expecting the worst, but this was even worse than I had conceived of (Darko 1998, pp. 137-38).

This issue of woman's exploitation in a patriarchal society surely impedes womenfolk's social and economic growth. As a scholar rightly puts it: "In the face of imperialist patriarchy, traditional African women in post-colonial Africa appear to have lost their image, myth and sacredness that represented their being and social existence" (Blay 2014: 3). On this note, men are determined to do whatever possible to exploit women. Indeed, the exploiter Osey helps his wife Kaye migrate to Frankfurt, Germany by painting in glowing colours what she stands to gain in Europe. Wickedly he compels and blackmails her into prostitution. In this regard, Osey takes Kaye's stark-naked pictures without her knowing it only to blackmail her whenevershe attempts to back out. Whenever Kaye tries to stop prostitution, Osey threatens to send Kaye's naked pictures to her family back home to inform them about her nauseating job. The homodiegetic narrator unveils Osey's manoeuvre in this way:

[...] then he coerced her into prostitution, pocketed every mark she made and kept her in the trade by blackmailing her with pictures he had clandestinely taken of her in action with different men. 'You back out today, tomorrow these pictures will be on their way back to your family at home', he had threatened whenever she mentioned her desire to get out of the business so for a whole year and a half Kaye worked for him (Darko 1998, p. 117).

Osey's attitude towards his 'wife' shows the proclivity of the post-colonial imperialist patriarchal system to exploit and keep women in thraldom. On this score, post-colonial African feminists' theories seek social change in women's status by changing the way male-controlled society portrays them.

\section{Conclusion}

In the light of the foregoing, Achebe presents the African woman as a second-rate person, very assertive, very hardworking, very dutiful, worthless, as an appendage of man, the embodiment of 
fertility, the seductress, and the one capable of nurturing peace and tranquility. Conversely, Amma Darko presents the African woman diversely as a person who is naïve, who is exploited easily, as a person who cannot make her own choice, as a sex commodity, and as property that is saleable to the highest bidder. Correspondingly, both Achebe and Darko have presented African women as people that are maltreated, people who should not resist the sex drive of men, means through which their parents get wealth, people who are hardworking, adjuncts of men, people who are created for the sake of men and people who are unable to choose by their own; the African woman being seen as substandard and subservient. In spite of the context of Chinua Achebe's and Amma Darko's respective postcolonial creative writings, they have used their fiction to tackle issues central to the perception of the African woman in fiction and in real life. They have succeeded in bringing to the fore the gender imbalances in patriarchal African societies. The plots in Darko's and Achebe's novels under scrutiny have reflected the quandary of the African woman trapped by the claws of patriarchy. It is therefore high time for all writers to present the developmental nature of the female character through a varied exploration of the theme of female assertiveness in the various societal facets which enslave the female. Basically, the thematic messages should enforce the fact that even in the face of deep rooted patriarchal nature of the society; African women should strive to assert themselves.

The feeling of naivety, inferiority and docility that is imbued in African women is made through the ideologies of patriarchy. It comes out that tradition has caused to African women more troubles and mortification than happiness. All the honour is the men's in Africa as Darko and Achebe's novels have depicted.

To achieve this, the African fictional prose narratives should stress gender complementarities between men and women in order to preserve and guarantee a harmonious and peaceful African societies where men and women work hands in hands.

\section{References}

Achebe, C. (2008). Things fall apart. Edinburgh: Heinemann.

African Literature. Trenton: Africa World Press.

Anyidoho, N. A. et al.(2016). Shakespeare lives in Ghana: Roles, representations and perceptions of women in contemporary Ghanaian society. Legon, Accra: The Institute of Statistical, Social and Economic Research (ISSER) / University of Ghana, ISSER Final Report for SLIG Project.

Ashcroft et al. (2007). Post-colonial studies: The key concepts. London: Routledge Taylor and Francis Group.

Blay A. R. (2014). The image of African women in a patriarchal society: A study of Buchi Emecheta's The Joys of Motherhood and Amma Darko's Beyond the Horizon. Kumasi: University of Education Winneba. (A thesis In Partial Fulfilment of the Requirements for Award of the Master of Philosophy of English Degree)

Busia, A. (1986). Parasites and prophets: The use of women in Ayi Kwei Armah's novels. In BoyceDavies, C. \& Graves, A. A. (Eds.), Ngambika: Studies of Women in

Darko, A. (1995). Beyond the Horizon. Edinburgh: Heinemann.

Diop, C.A. (1989). The cultural unity of Black Africa: domains of matriarchy and patriarchy in classical antiquity. London: Karnak House.

Foucault, M. (1980). Power/Knowledge: Selected Interviews and other Writings. New York: Pantheon. 
Iyasere, S. (1969). Narrative techniques in Things Fall Apart. In Killam, G.D. (ed.) Critical Perspectives on Chinua Achebe. London: Heyman.

Mikell, Gwendolyn. (1997). African feminism: The politics of sub-saharan Africa. Pennsylvania: University of Pennsylvania.

Owusu, K. (1990). Cannons under Siege: Blackness, femaleness and Ama Ata Aidoo's “Our Sister Killjoy”. Callalloo, 13, 341-363.

Peter, Z. W. (2010). The depiction of female characters in literary works written by males. Unpublished Master's Dissertation. Port Elizabeth: Nelson Mandela Metropolitan University.

Strong-Leek, L. (2001). Reading as a woman: Chinua Achebe's Things Fall Apart and feminist criticism. African Studies Quarterly, Volume 5, Issue 2. pp. 29-35. 